\title{
Continuous Ethanol Fermentation of Lactose by a Recombinant Flocculating Saccharomyces cerevisiae Strain
}

\author{
Lucília Domingues, Maria M. Dantas, Nelson Lima, José A. Teixeira \\ Centro de Engenharia Biológica-IBQF, Universidade do Minho, Braga, \\ Portugal; telephone: +351-53-604400; fax: +351-53-678986; \\ e-mail: jateixeira@deb.uminho.pt
}

Received 9 October 1998; accepted 8 March 1999

\begin{abstract}
Alcohol fermentation of lactose was investigated using a recombinant flocculating Saccharomyces cerevisiae, expressing the LAC4 (coding for $\beta$-galactosidase) and $L A C 12$ (coding for lactose permease) genes of Kluyveromyces marxianus. Data on yeast fermentation and growth on a medium containing lactose as the sole carbon source are presented. In the range of studied lactose concentrations, total lactose consumption was observed with a conversion yield of ethanol close to the expected theoretical value. For the continuously operating bioreactor, an ethanol productivity of $11 \mathrm{~g} \mathrm{~L}^{-1} \mathrm{~h}^{-1}$ (corresponding to a feed lactose concentration of $50 \mathrm{~g}$ $\mathrm{L}^{-1}$ and a dilution rate of $0.55 \mathrm{~h}^{-1}$ ) was obtained, which is 7 times larger than the continuous conventional systems. The system stability was confirmed by keeping it in operation for 6 months. (c) 1999 John Wiley \& Sons, Inc. Biotechnol Bioeng 64: 692-697, 1999.
\end{abstract}

Keywords: lactose fermentation; recombinant yeast; ethanol production; continuous culture; flocculation; airlift

\section{INTRODUCTION}

Cheese whey is the liquid remaining following the precipitation and removal of milk casein during cheese making. This byproduct represents an important environmental problem because of the high volumes produced (to make $1 \mathrm{~kg}$ of cheese, $9 \mathrm{~kg}$ of whey is generated) and its high organic matter content, exhibiting a BOD (biochemical oxygen demand) ranging from 30 to $50 \mathrm{~g} \mathrm{~L}^{-1}$ and a COD (chemical oxygen demand) ranging from 60 to $80 \mathrm{~g} \mathrm{~L}^{-1}$. The main component responsible for the high BOD and COD is lactose, as the protein recovery reduces the COD of the whey only about $10 \mathrm{~g} \mathrm{~L}^{-1}$ (Siso, 1996). On the other hand, lactose represents a potential substrate for some microorganisms. Therefore, the development of a high-productivity lactose fermenting process is of prime importance since alcoholic fermentation of whey is an alternative that has been considered for cheese whey bioremediation (Mann, 1980; Mawson, 1987). However, existing systems make use of

Correspondence to: J. A. Teixeira

Contract grant sponsors: IBQF; FCT

Contract grant numbers: PRAXISXXI/BD/11306/97 (FCT) batch processes that, as is well known, have low productivities.

A high productivity keeping the substrate conversion and product concentration maximal can be accomplished by having high concentration of microorganisms in the fermentor. As the active population increases in the bioreactor, the conversion rate of substrate into products is also expected to increase (Teixeira et al., 1990). There are several techniques which allow for the operation with a high biomass concentration. Immobilization or gel inclusion, mechanical recycling techniques, as well as utilizing the natural ability of several microorganisms for aggregation and flocculation are some of them. As main advantages from the alternative processes, flocculation systems present low associated capital and operational costs and design simplicity. Moreover, it enables the treatment of large substrate volumes, minimizes the contamination risks, and allows for increasing biomass concentration without physically confining the microorganisms into a support. In addition, separation of cells from media is facilitated, reducing downstream processing costs.

Saccharomyces cerevisiae is the microorganism of choice in industrial biotechnology. Unfortunately, S. cerevisiae cannot metabolize lactose, which must be hydrolyzed before the resultant glucose and galactose can be utilized. Such a procedure is hampered by high concentrations of extracellular glucose, which cause catabolite repression of galactose utilization (Champagne and Goulet, 1988; Gancedo, 1998). Consequently, several approaches have been tried to construct genetically engineered $S$. cerevisiae strains able to metabolize lactose. One of the methodologies employed for that purpose was protoplast fusion, resulting in hybrids of the strains S. cerevisiae and Kluyveromyces lactis capable of utilizing lactose (Farahnak et al., 1986). However, the recombinant fusants had reduced genetic stability. Another approach that has been considered is the cloning of genes that code for $\beta$-galactosidase and lactose permease of $K$. lactis in S. cerevisiae (Sreekrishna and Dickson, 1985; Russel, 1986). Alternative strategies involved the construction of $S$. cerevisiae cells releasing $\beta$-galactosidase into the culture medium, either by secretion (Kumar et al., 1992) or by lysis of the recombinant cells, as a result of overexpression of the transcriptional activator 
GAL4 (Porro et al., 1992) or by the use of osmotic-remedial thermosensitive autolytic mutants (Becerra et al., 1997). More recently, the cloning and expression of the gene for $\beta$-galactosidase, as well as the lactose permease gene from Candida pseudotropicalis in S. cerevisiae cells has been reported (Tretiak et al., 1998). However, the developed processes based on metabolically engineered $S$. cerevisiae cells present rather modest ethanol productivity.

This study uses a recombinant flocculent $S$. cerevisiae strain for ethanol production from lactose. Continuous culture operation allowed for a very high ethanol productivity which raises new perspectives for the development of a large-scale economically feasible process based on whey fermentation.

\section{MATERIAL AND METHODS}

\section{(a) Microorganism}

A recombinant $S$. cerevisiae flocculent strain expressing the $L A C 4$ (coding for $\beta$-galactosidase) and LAC12 (coding for lactose permease) of $K$. lactis was used. The pKR1B-Lac4-1 vector (ATCC No. 40186, U.S. Patent No. 5,047,340 dated September 10, 1991) harboring the LAC4 and LAC12 genes of $K$. lactis, was co-transformed with a $9 \mathrm{~kb}$ pYAC4 (Sigma $\mathrm{V}-0758$, Lot. 103H6770) linear fragment into the flocculent host strain S. cerevisiae NCYC869-A3 which is a uracildeficient strain (Lima et al., 1995). Four clones expressing $\beta$-galactosidase activity were obtained, and only two kept a stable $\mathrm{Lac}^{+}$phenotype. From these two, one showed better

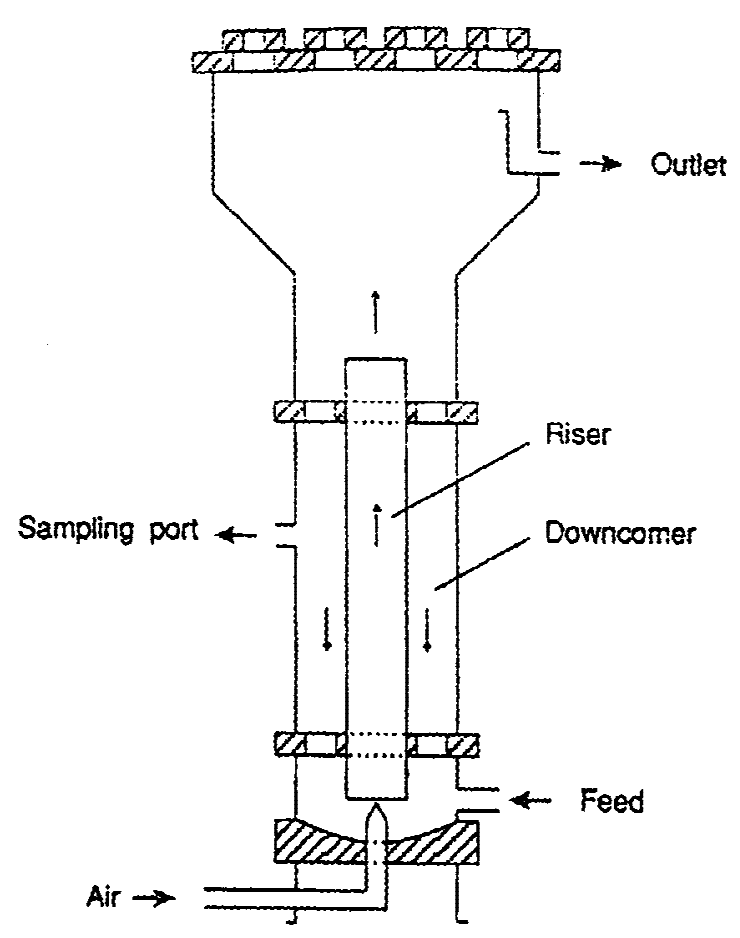

Figure 1. Schematic representation of the airlift bioreactor. fermentation and growth parameters on lactose; it was taken for further studies and named T1 (Domingues et al., 1999).

\section{(b) Culture Media and Shake Flask Cultures}

The recombinant yeast was maintained at $4{ }^{\circ} \mathrm{C}$ on slants or at $-80^{\circ} \mathrm{C}$ in permanent culture of a YNB selective medium having the following composition: $6.7 \mathrm{~g} \mathrm{~L}^{-1}$ yeast nitrogen base (w/o amino acids), $20 \mathrm{~g} \mathrm{~L}^{-1}$ lactose. SSlactose medium was used for all experiments and is composed as follows: $\mathrm{KH}_{2} \mathrm{PO}_{4}, 5 \mathrm{~g} \mathrm{~L}^{-1} ;\left(\mathrm{NH}_{4}\right)_{2} \mathrm{SO}_{4}, 2 \mathrm{~g} \mathrm{~L}^{-1} ; \mathrm{MgSO}_{4} \cdot 7 \mathrm{H}_{2} \mathrm{O}, 0.4$ $\mathrm{g} \mathrm{L}^{-1}$; yeast extract, $1.0 \mathrm{~g} \mathrm{~L}^{-1}$. The carbon source was lactose, with an initial concentration that varied in the range 20-50 $\mathrm{g} \mathrm{L}^{-1}$. The complete YEPG medium used in the plasmid stability determination is composed as follows: glucose, $20 \mathrm{~g} \mathrm{~L}^{-1}$; peptone, $20 \mathrm{~g} \mathrm{~L}^{-1}$; yeast extract, $10 \mathrm{~g} \mathrm{~L}^{-1}$. Yeast cultures were carried out at $30^{\circ} \mathrm{C}$ by rotary shaker with $150 \mathrm{rpm}$ agitation, in $100 \mathrm{~mL}$ of culture medium in 250-mL Erlenmeyer flasks. The flasks were inoculated with $1 / 10$ volume of preinocula grown overnight, at $30^{\circ} \mathrm{C}$, in the respective medium.

\section{(c) Continuous Culture Experiments}

SSlactose medium was used at an initial lactose concentration of $50 \mathrm{~g} \mathrm{~L}^{-1}$.

An airlift bioreactor of the concentric draft tube made of Perspex was used which is shown schematically in Fig. 1. Filtered air is injected immediately below the annulus of the riser, thus promoting an ejection effect responsible for circulation inside the reactor. At the top, the inverted conic enlargement provides a degassing area and floc deceleration zone. Part of the fermented liquid sheers off naturally and the remainder is recirculated along with biomass into the downcomer and again into the riser. A vertical barrier surrounds the outlet pool, thus preventing the biomass particles from being driven off by the effluent. The working volume is $5.5 \mathrm{~L}$, and the riser-downcomer diameter ratio is 0.46 . Fresh medium was fed at the bottom of the reactor. The regulation system allows temperature control at $30 \pm 1{ }^{\circ} \mathrm{C}$; foam level control by addition of antifoam (Sigma A-5551); and $\mathrm{pH}$ control by automatic addition of ammonia, the setpoint being fixed at $\mathrm{pH} 4.0 \pm 0.1$. The system was aerated with filtered air at a rate of (0.0800-1.0000) $\pm 0.0002 \mathrm{vvm}$. Dilution rate was varied during the experiments in the range of $0.04-0.6 \mathrm{~h}^{-1}$.

In earlier studies, the mixing behavior of the reactor was found by a tracer method utilizing methylene blue to reproduce well that of an ideal continuous stirred tank reactor (CSTR) for all operating conditions (Sousa et al., 1994).

For start-up of continuous culture, cells were grown in a 2-L Erlenmeyer flask filled with $1 \mathrm{~L}$ of culture medium, for $24 \mathrm{~h}$. The cell suspension was then aseptically transferred to the fermentor which was kept in batch operation for $24 \mathrm{~h}$ before switching on the feeding. 


\section{(d) Analysis}

The cell concentration, i.e., biomass concentration, was estimated by the dry weight method. The dry weight cell concentration was determined by filtering the sample through $0.2-\mu \mathrm{m}$ filter paper and then dried at $105^{\circ} \mathrm{C}$ for 24 $\mathrm{h}$. The lactose concentration was determined by the DNS method (Miller, 1959). Ethanol concentration was measured by an HPLC method (Poyspher CH CA column, Merck). The solvent used was $0.1 \mathrm{~N} \mathrm{H}_{2} \mathrm{SO}_{4}$, at a flow rate of $0.7 \mathrm{~mL}$ $\min ^{-1}$, while detection was effected with a refractive-index detector. Temperature was maintained at $60^{\circ} \mathrm{C}$. Cell viability was estimated by the vital methylene blue staining method and cell counting in Neubauer chamber. To determine the fraction of plasmid-bearing cells, samples from the yeast culture were diluted and $100 \mu \mathrm{L}$ of these solutions was spread onto both YNB selective medium and YEPG nonselective plates and then incubated at $30^{\circ} \mathrm{C}$ for 2 days. The fraction of plasmid-bearing cells was found by counting the colonies on both types of plates.

\section{(e) Flocculation Assay}

Yeast cells were washed twice with $1.5 \mathrm{~g} \mathrm{~L}^{-1} \mathrm{NaCl}, \mathrm{pH} 3.0$, solution. A 24-mL volume of cell suspension was placed on a $25-\mathrm{mL}$ graduated cylinder. Then, $1 \mathrm{~mL}$ of a $100 \mathrm{mM}$ $\mathrm{CaCl}_{2}, \mathrm{pH} 3.0$, solution was added and the solution was immediately mixed by inversion 18 times. Samples of 200 $\mu \mathrm{L}$ were taken at the $20-\mathrm{mL}$ level at different times. To ensure floc dispersion samples were treated with $\mathrm{NaCl}$ solution before OD reading at $620 \mathrm{~nm}$ (Soares et al., 1992). The normalized cell concentration defined as the ratio between actual and initial cell concentration was plotted against sedimentation time. A sedimentation profile was then obtained.

\section{RESULTS AND DISCUSSION}

Figure 2 shows the time course of cell, ethanol, and lactose concentrations for two different initial lactose concentrations $\left(20\right.$ and $\left.50 \mathrm{~g} \mathrm{~L}^{-1}\right)$ in shake flask cultures of the recombinant strain. As can be observed from Fig. 2, in less than $40 \mathrm{~h}, 50 \mathrm{~g} \mathrm{~L}^{-1}$ of lactose is metabolized by the recombinant strain. In Table I, the fermentation parameters for the two initial lactose concentrations are presented. An increase in the initial lactose concentration led to an increase in biomass concentration and ethanol concentration. However, the increase in biomass concentraton is very slight when compared to the increase on the ethanol production. This can be related to the limited respiratory capacity of $S$. cerevisiae as described in the bottleneck model (Sonnleitner and Käppeli, 1986). The growth rate exhibited by the recombinant strain in SSlactose medium was very good having mean doubling times of 2-3 h. The maximum ethanol concentration increased with the initial lactose concentration and a bioconversion yield of $60 \%$ of the theoretical value (i.e., assuming a production of $4 \mathrm{~mol}$ ethanol per mol
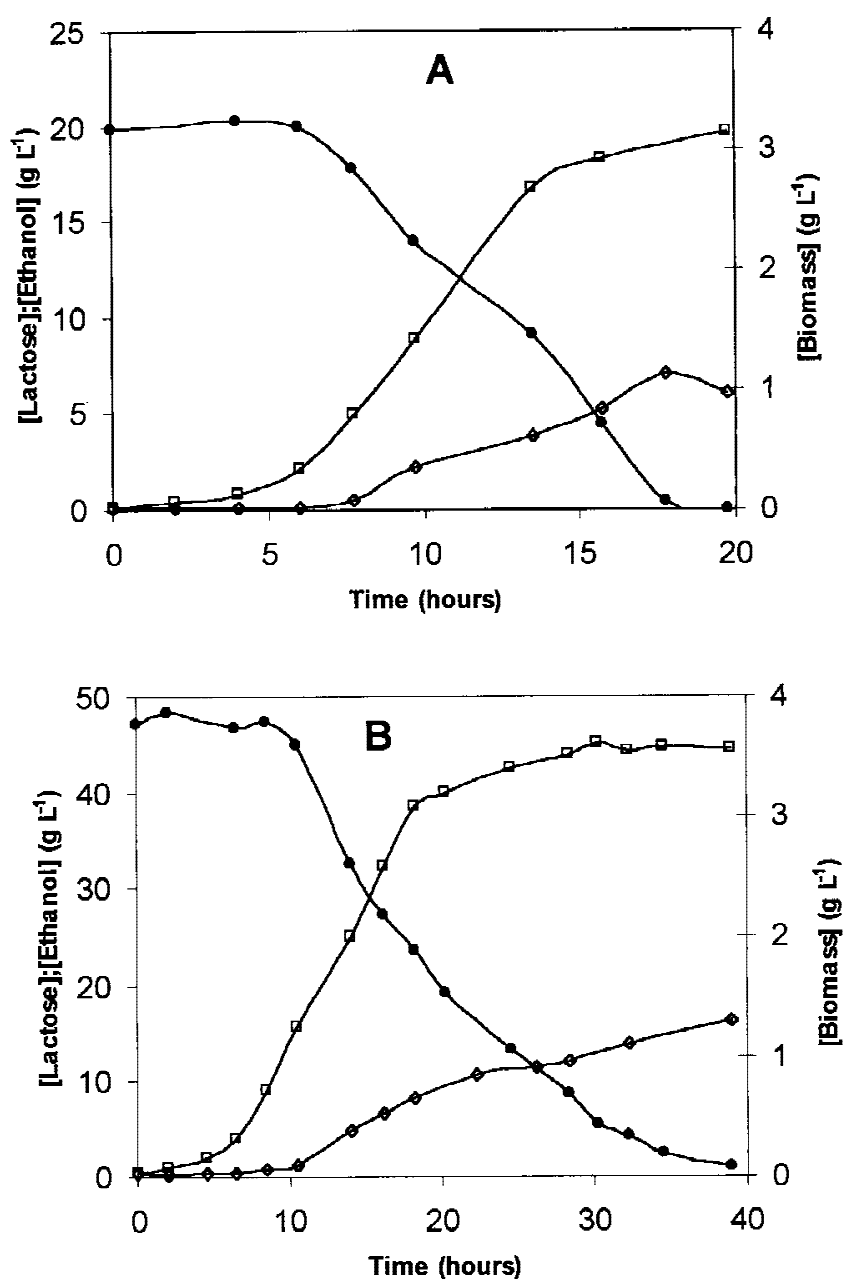

Figure 2. Cell $(\square)$, lactose $(\bullet)$, and ethanol ( $\bullet$ ) concentration profiles for $20 \mathrm{~g} \mathrm{~L}^{-1}$ (A) and $50 \mathrm{~g} \mathrm{~L}^{-1}$ (B) initial lactose concentrations in shake flask culture of the recombinant yeast in SSlactose medium.

lactose consumed) was obtained in these assays. The viability was also monitored and found to be very high (90$100 \%)$ during all the fermentation experiments. With this assay, the stability of the $\mathrm{Lac}^{+}$phenotype in SSlactose medium was confirmed and continuous fermentation experiments with initial lactose concentration of $50 \mathrm{~g} \mathrm{~L}^{-1}$ with this strain followed the batch assays.

In earlier studies, some flocculence instability for the recombinant strain was observed when grown in shake flask

Table I. Variation of fermentation parameters with initial lactose concentration, $20 \mathrm{~g} \mathrm{~L}^{-1}$ (A) and $50 \mathrm{~g} \mathrm{~L}^{-1}$ (B), for the recombinant strain in SSlactose medium in shake flask culture.

\begin{tabular}{lcc}
\hline & $\mathrm{A}$ & $\mathrm{B}$ \\
\hline Initial lactose concentration $\mathrm{S}_{\mathrm{f}}\left(\mathrm{g} \mathrm{L}^{-1}\right)$ & 19.9 & 47.2 \\
Maximum specific growth rate $\mu\left(\mathrm{h}^{-1}\right)$ & 0.44 & 0.33 \\
Ethanol productivity $\left(\mathrm{g} \mathrm{L}^{-1} \mathrm{~h}^{-1}\right)$ & 0.40 & 0.45 \\
Final biomass concentration $X\left(\mathrm{~g} \mathrm{~L}^{-1}\right)$ & 3.2 & 3.7 \\
Final ethanol concentration $\mathrm{P}\left(\mathrm{g} \mathrm{L}^{-1}\right)$ & 6.1 & 15.6 \\
Ethanol conversion yield $\eta(\%)$ & 57 & 60 \\
\hline
\end{tabular}


culture at $150 \mathrm{rpm}$ : the flocculence grade was lower than that obtain in static culture (Domingues et al., 1999). While for the cells grown in static culture only $5 \%$ of the cells remained in suspension after the sedimentation test, the cells in suspension were $65 \%$ of the total for the cells grown under $150 \mathrm{rpm}$ agitation. It is well known that continuous operation in a bioreactor with an adequate design (Teixeira et al., 1990) can be used to select for most flocculating cells from a mixed culture, allowing for the possibility of accumulating a high biomass concentration in the bioreactor with the inherent advantages of operating as a continuous high cell density system. The reactor for continuous experiments was chosen taking into account the flocculence instability of the recombinant strain, and the consequent need for selection for the most flocculating cells. This was the main reason for choosing an airlift bioreactor which exhibits low shear stresses due to the absence of mechanical agitation (Vicente and Teixeira, 1995). The existence of the sedimentation zone in the top of the reactor coupled with the semicylindrical fence in the outlet region (see Materials and Methods for details), helped in the retention of the flocculent cells, the nonflocculent cells being washed-out. With this device, the selection and corresponding retention of yeast flocculent cells inside the bioreactor was possible. In Fig. 3 the sedimentation profile of yeast cells taken from the interior of the continuous bioreactor at different periods after start-up is represented, confirming the selection of the cells with larger flocculating ability. After 13 days of continuous operation, selection of a $100 \%$ flocculent culture was possible. It is worth noting that in just 1 day of operation the amount of flocculent cells increased from $30 \%$ to $65 \%$ of the total cells.

In Fig. 4 the different fermentation parameters measured during 43 days of operation of the continuous bioreactor at increasing dilution rates are represented. The operation started at a $0.04 \mathrm{~h}^{-1}$ dilution rate and each time a residual

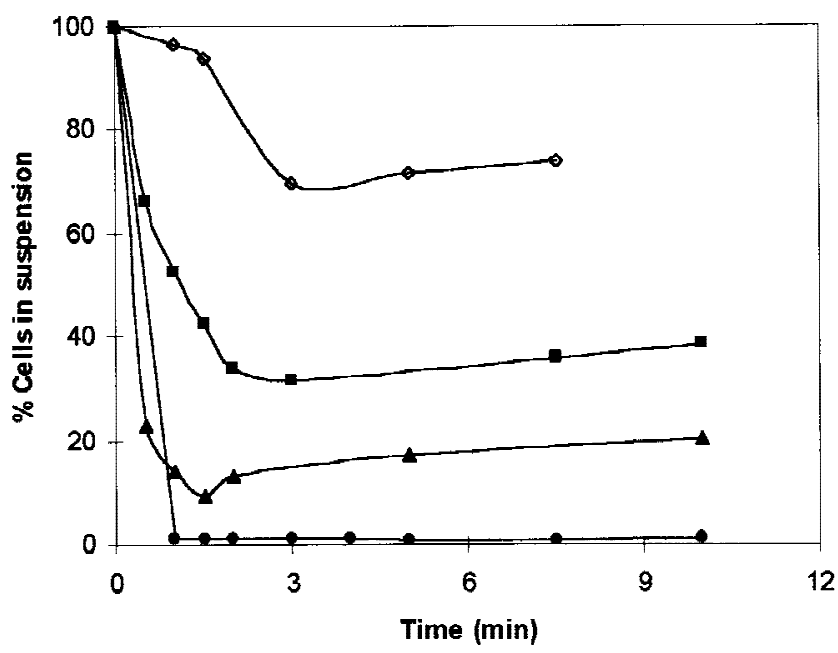

Figure 3. Sedimentation profile for the recombinant cells before starting the continuous operation $(\diamond)$ and at $1(\boldsymbol{\square}), 6(\boldsymbol{\Delta})$, and $13(\bullet)$ days of continuous operation.

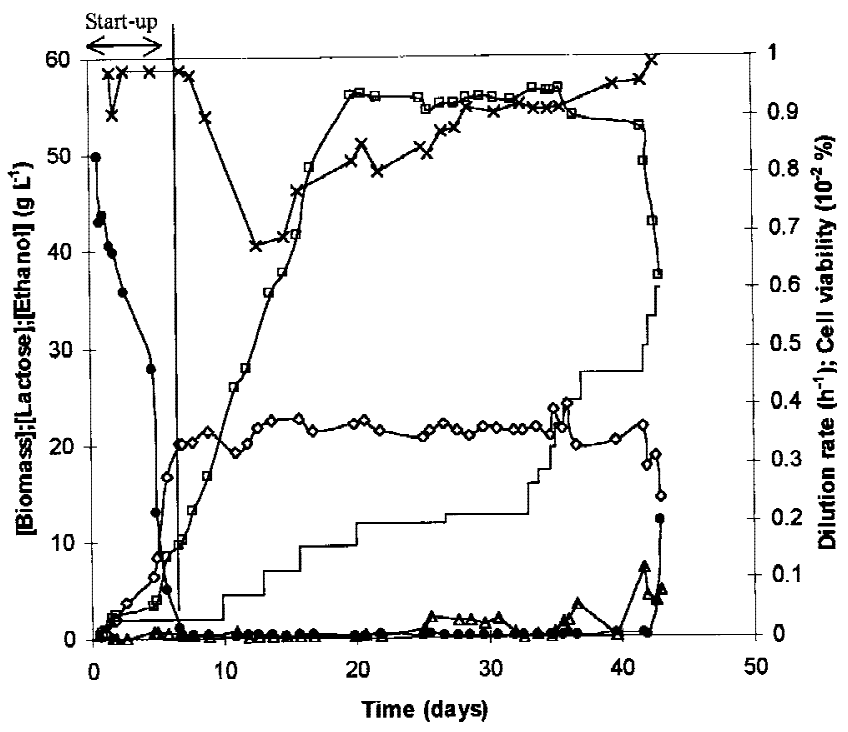

Figure 4. Continuous fermentation time courses of lactose concentration $(\diamond)$; ethanol concentration $(\diamond)$; cell concentration in the bioreactor $(\square)$ and in the effluent $(\triangle)$; cell viability $(x)$ profiles with increasing dilution rates (一) for the recombinant $\mathrm{T} 1$.

lactose concentration $\left(<1 \mathrm{~g} \mathrm{~L}^{-1}\right)$ was obtained; the dilution rate (up to $0.6 \mathrm{~h}^{-1}$ ) was increased stepwise.

A start-up period of 6 days was observed, and this long period was due to the retention of the yeast flocculating cell cultures. Continuous feeding was started when a steady increase in biomass concentration was observed inside the bioreactor. For all tested dilution rates, and until the limit dilution rate $\left(0.55 \mathrm{~h}^{-1}\right)$, a lactose concentration below $0.5 \mathrm{~g}$ $\mathrm{L}^{-1}$ was always obtained.

The cell concentration in the bioreactor increased up to a dilution rate $(D)$ of $0.2 \mathrm{~h}^{-1}$. For higher values of $D$ and until $0.45 \mathrm{~h}^{-1}$, the biomass concentration in the bioreactor remained constant. For $D$ above $0.45 \mathrm{~h}^{-1}$, a pronounced decrease in the biomass concentration was observed corresponding also to an increase in biomass concentration in the outlet. The maximum cell concentration obtained was $56 \mathrm{~g}$ $\mathrm{L}^{-1}$ being this value 16 times higher than the one obtained for batch cultures. The cell concentration in the effluent was always below $2 \mathrm{~g} \mathrm{~L}^{-1}$ until a dilution rate of $0.4 \mathrm{~h}^{-1}$. At higher dilution rates, strong oscillations in the cell concentration in the effluent was observed, approaching the situation where biomass reduction in the bioreactor was observed, $0.45 \mathrm{~h}^{-1}$. It is worth noting that an increase in the air flow rate was needed when increasing dilution rate in order to prevent the bioreactor from stalling. This increase in air flow rate is the main responsible for the maintenance of a constant cell concentration at dilution rates higher than 0.2 $\mathrm{h}^{-1}$. Due to the increase in mixing intensity, a larger amount of cells is washed-out from the bioreactor meaning that the rate of cells growth equals the rate of cells removed in the effluent.

During all the period of operation (6 months) the cell viability varied from $70 \%$ to $99 \%$. Whenever the cell viability decreased, a purge was made so that the system could 
recover and cell viability could increase (as shown in Fig. 4 at day 10 of operation). Plasmid stability was also monitored throughout the continuous experiment and found to be very high and similar to the cell viability. As the lactose is the sole carbon source, if plasmids leak from the cells, these cells will not be able of growing anymore and will die. Under positive selective pressure conditions (lactose as sole carbon source), cells have to keep the plasmid in order to retain viability.

During all the operation time of the bioreactor (6 months) at several dilution rates, an oscillatory behavior in biomass retention was observed. The system accumulated biomass until its limit capacity, and when the limit value of approximately $56 \mathrm{~g} \mathrm{~L}^{-1}$ was reached, it spontaneously purged off leading to a new accumulation cycle. For this reason, the biomass concentration in the effluent was slightly oscillating, even in stationary state. Anyway, total lactose consumption was always obtained. It is thought that this spontaneous purge is associated with high cellular activity, resulting from biomass accumulation, with a corresponding high production of $\mathrm{CO}_{2}$ that is, as the fermentation proceeds, accumulated inside the flocs. After coalescing into sufficiently large bubbles, $\mathrm{CO}_{2}$ ascends, dragging appreciable quantities of biomass to the degassing zone, that are easily removed by the rapidly outflowing effluent.

Considering that at a given dilution rate, when residual concentration of lactose is achieved, a pseudo-stationary state has been reached, i.e., lactose consumption and ethanol production have reached constant values, the following expressions can be used, assuming that the reactor maintains the CSTR behavior (Sousa et al., 1994):

$$
\begin{aligned}
& q_{\mathrm{s}}^{*}=-\frac{1}{X^{*}} D\left(S^{*}-S_{\mathrm{f}}\right) . \\
& q_{\mathrm{p}}^{*}=\frac{1}{X^{*}} D P^{*} .
\end{aligned}
$$

For the calculation of these parameters only the amount of viable cells was considered. Taking into account the values of pseudo-stationary state, the effect of the dilution rate on the specific lactose consumption rate $\left(q_{\mathrm{s}}{ }^{*}\right)$ and the specific ethanol production rate $\left(q_{\mathrm{p}}^{*}\right)$ were analyzed (Fig. 5). An increase in the dilution rate up to the limit dilution rate $(0.55$ $\mathrm{h}^{-1}$ ) leads to a similar increase in both the specific lactose consumption rate and specific ethanol production rate in pseudo-stationary state. This increase is more pronounced at dilution rate values higher than $0.2 \mathrm{~h}^{-1}$, corresponding to the situation when biomass concentration remains constant inside the bioreactor. The similarity of the dependence of $q_{\mathrm{s}}{ }^{*}$ and $q_{\mathrm{p}}{ }^{*}$ with the dilution rate also puts in evidence that the metabolic state of viable cells in the flocs was kept constant at the dilution rates and operational conditions studied.

This is also confirmed by analyzing the stoichiometry of lactose conversion to ethanol, expressed by the ethanol conversion yield $(\eta)$,

$$
\eta(\%)=\frac{P}{\left(S_{\mathrm{f}}-S\right) 0.538} 100 .
$$

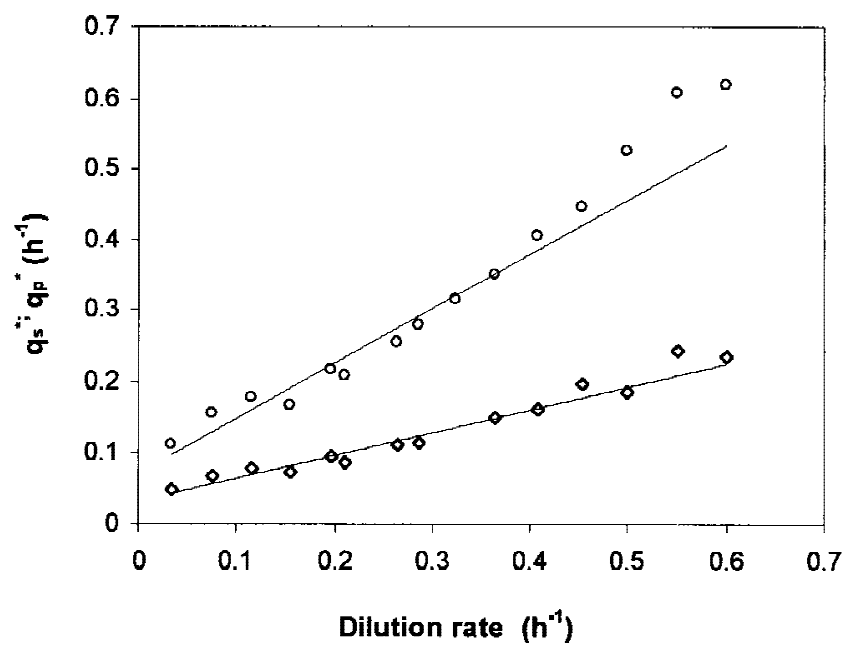

Figure 5. Effect of the dilution rate on the specific lactose consumption rate, $q_{\mathrm{s}}{ }^{*}(\bigcirc)$, and specific ethanol production rate, $q_{\mathrm{p}}{ }^{*}(\diamond)$.

Another parameter of major importance in the system is the ethanol productivity, defined as

$$
Q_{\mathrm{p}}=D P \text {. }
$$

In Fig. 6, the ethanol productivity, residual lactose concentration, and ethanol conversion yield for different dilution rates are presented. In the ethanol conversion yield, a mean value of $80 \%$ is obtained regardless of the dilution rate, confirming the maintenance of cell metabolic activity. As can be observed, the ethanol productivity has a maximum, $11 \mathrm{~g} \mathrm{~L}^{-1} \mathrm{~h}^{-1}$, for a dilution rate of $0.55 \mathrm{~h}^{-1}$ even though at this dilution rate the residual lactose concentration had already increased to $3 \mathrm{~g} \mathrm{~L}^{-2}$. It is clear that the best operational dilution rate would be $0.45 \mathrm{~h}^{-1}$; even though higher productivities can be obtained at higher dilution rates, the operation of the bioreactor becomes very unstable.

The flocculation characteristics were kept constant during

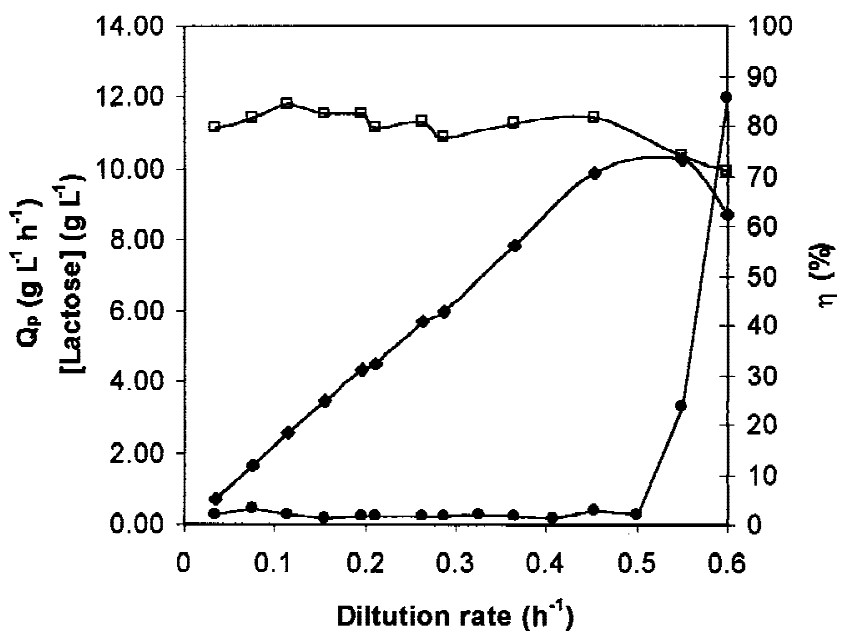

Figure 6. Variation of ethanol productivity ( ), lactose concentration $(\bullet)$ inside the bioreactor, and ethanol conversion yield $(\square)$ with the dilution rate. 
the entire working period. In 6 months of operation this system proved to be stable with total conversion of lactose and constant ethanol conversion yield.

\section{CONCLUSIONS}

Batch experiments showed that the recombinant $S$. cerevisiae strain used in this work was able to consume $50 \mathrm{~g} \mathrm{~L}^{-1}$ of lactose with high ethanol yields. By using continuous bioreactor set-up, an improvement in the flocculation capacity as well as stability for the recombinant strain was obtained. For the continuous operating bioreactor, an ethanol productivity of $11 \mathrm{~g} \mathrm{~L}^{-1} \mathrm{~h}^{-1}$ with a bioconversion yield as high as $80 \%$ of the theoretical value and total lactose consumption was obtained. These results are a great improvement in the processes based on metabolically engineered $S$. cerevisiae cells, as values such as $0.1-0.2 \mathrm{~g} \mathrm{~L}^{-1}$ $\mathrm{h}^{-1}$ (Porro et al., 1992), 0.139-0.4 $\mathrm{g} \mathrm{L}^{-1} \mathrm{~h}^{-1}$ (Ramakrishna and Hartley, 1993), and $1 \mathrm{~g} \mathrm{~L}^{-1} \mathrm{~h}^{-1}$ (Compagno et al., 1995) for ethanol productivity from lactose are referred in literature. It is worth noting that these values refer to batch processes. Moreover, in what concerns continuous high cell density lactose alcoholic fermentation these results are similar to those obtained with $K$. marxianus strain (Teixeira et al., 1990), although a better flocculation stability is achieved with the strain presented in this work. This raises new perspectives for the alcoholic fermentation of whey.

\section{NOMENCLATURE}

\author{
$\mathrm{P}$ ethanol concentration \\ $\mathrm{S}$ lactose concentration \\ $\mathrm{X}$ biomass concentration \\ Superscripts or subscripts \\ * value at pseudo-stationary state \\ f feed concentration
}

The authors acknowledge the financial support provided by the Instituto de Biotecnologia e Química Fina (IBQF), Portugal. Lucília Domingues was supported by a grant (PRAXIS XXI/BD/ 11306/97) from FCT (Fundação para a Ciência e Tecnologia), Portugal.

\section{References}

Becerra M, Cerdan E, Gonzalez Siso MI. 1997. Heterologous Kluyveromyces lactis $\beta$-galactosidase production and release by Saccharomyces cerevisiae osmotic-remedial thermosensitive autolytic mutants. Biochim Biophys Acta 1335:235-241.
Champagne CP, Goulet J. 1988. Growth of baker's yeast (Saccharomyces cerevisiae) in lactose-hydrolysed cheese-whey ultrafiltrate. Can Inst Food Sci Technol 21:545-548.

Compagno C, Porro D, Smeraldi C, Ranzi BM. 1995. Fermentation of whey and starch by transformed Saccharomyces cerevisiae cells. Appl Microbiol Biotechnol 43:822-825.

Domingues L, Teixeira JA, Lima N. 1999. Construction of a flocculent Saccharomyces cerevisiae fermenting lactose. Appl Microbiol Biotechnol 51:621-626.

Farahnak F, Seki T, Ryu DY, Ogrydziak D. 1986. Construction of lactoseassimilating and high ethanol producing yeasts by protoplast fusion. Appl Environ Microbiol 51:362-367.

Gancedo J. 1998. Yeast carbon catabolite repression. Microbiol Mol Biol Rev 62:334-361.

Kumar V, Ramakrishna S, Teeri TT, Knowles JKC, Hartley BS. 1992. Saccharomyces cerevisiae cells secreting an Aspergillus niger $\beta$-galactosidase grown on whey permeate. Bio/Technology 10:82-85.

Lima N, Moreira C, Teixeira JA, Mota M. 1995. Introduction of flocculation into industrial yeast, Saccharomyces cerevisiae saké, by protoplast fusion. Microbios 81:187-197.

Mann EJ. 1980. Alcohols from whey. Dairy Ind Int 3:47-48.

Mawson AJ. 1987. Ethanol Production from whey in New Zealand. Aust J Biotechnol 1:64-73.

Miller GL. 1959. Use of dinitrosalicylic acid reagent for determination of reducing sugar. Anal Chem 31:426-428.

Porro D, Martegani E, Ranzi BM, Alberghina L. 1992. Lactose/whey utilization and ethanol production by transformed Saccharomyces cerevisiae cells. Biotechnol Bioeng 39:799-805.

Ramakrishnan S, Hartley BS. 1993. Fermentation of lactose by yeast cells secreting recombinant fungal lactase. Appl Environ Microbiol 59: 4230-4235.

Russel I. 1986. Will a recombinant DNA yeast be able to solve whey disposal problems? Trends Biotechnol 4:107-108.

Siso GIM. 1996. The biotechnological utilization of cheese whey: A review. Bioresource Technol 57:1-11.

Soares EV, Teixeira JA, Mota M. 1992. Interaction between flocculent and nonflocculent cells of Saccharomyces cerevisiae. Can J Microbiol 38: 969-974.

Sonnleitner B, Käppeli O. 1986. Growth of Saccharomyces cerevisiae is controlled by its limited respiratory capacity: Formulation and verification of a hypothesis. Biotechnol Bioeng 28:927-937.

Sousa ML, Mota M, Teixeira JA. 1994. Influence of operational parameters on the start-up of a flocculation airlift bioreactor. Colloids Surf B: Biointerfaces 2:181-188.

Sreekrishna K, Dickson RC. 1985. Construction of strains of Saccharomyces cerevisiae that grow on lactose. Proc Natl Acad Sci USA 82: 7909-7913.

Teixeira JA, Mota M, Goma G. 1990. Continuous ethanol production by a flocculating strain of Kluyveromyces marxianus: bioreactor performance. Bioprocess Eng 5:123-127.

Tretiak KA, Zakal'skii AE, Gudz' SP. 1998. The cloning and expression of the gene for $\beta$-galactosidase from Candida pseudotropicalis yeasts in Saccharomyces cerevisiae cells. Mikrobiol Z 60:57-66.

Vicente AA, Teixeira JA. 1995. Hydrodynamic performance of a threephase airlift bioreactor with an enlarged degassing zone. Bioprocess Eng 14:17-22. 